Troyacademy 5 (1), 231-246, 2020

Geliş/Received: 16.08.2019 • Kabul / Accepted: 06.01.2020

doi: DOI: 10.31454 / usb.723535

\title{
Tanzimat Dönemi Boyunca Türk Siyasal Hayatında Değişim ve Süreklilik
}

Halil KANADIKIRIK *

\section{Öz}

Bu çalş̧ma Türk siyasal kültürü açısından hayatî önemi haiz bir dönemi, Tanzimat Devri’ni odağa almaktadır. Ancak Türk modernleșmesinin eğilimlerine ilişkin kapsamlı bir analize ulaşabilmek amacıyla tarihsel çerçeve, 19. yüzyılın başlarından II. Abdülhamid'in Meclis-i Mebusan’ı süresiz tatil ettiği yıla kadar genişletilmiştir. Bu zaman kesiti boyunca siyasal seçkinler ile kurumların dönüşümünün niteliği irdelenmiștir. Tüm radikal dönüşümlere rağmen, İmparatorluk geçmişinden tevarüs edilen klasik meşru otoriteye ilişkin süreklilikler tespit edilmiştir. Bu bağlamda siyasal modernleşmenin klasik siyasal kültürün ana hatlarını korumaya yönelik bir yol tercih ettiği gösterilmiştir. Böylelikle çok-dilli ve çok-dinli toplumsal yapıya hükmeden imparatorluğun siyasal seçkinlerinin her türlü krize, bütünlüğü korumak için klasik-geleneksel reflekslerle yanıt verdiği ileri sürülmüştür. Neticede ise Tanzimat Devri’nde otoritenin bürokratik örgüt içinde yayılmasına karşın, ciddi bir kriz anında tekrar ve bu defa çelişkili yapısıyla yeni bir patrimonyal rejimin kurulabildiği gösterilmek istenmiştir.

Anahtar Kelimeler: Gelenek, Meşruiyet, Modernleşme, Siyasal Kültür, Tanzimat. JEL Kodları: F54, H19, H82, H83, H89, P26, P41, P49.

\section{Change and Continuity in Turkish Political Life During the Tanzimat Era}

\begin{abstract}
This study has focused on a vital period from the viewpoint of Turkish political culture, Tanzimat Era. However, in order to reach a comprehensive analysis regarding to dispositions of the Turkish modernization the historical frame has been extended from the beginnings of the $19^{\text {th }}$ century to the year when Abdülhamid II suspended the Chamber of Deputies indefinitely. Within this time period characteristic of the transition of the political elites and the institutions has been scrutinized. Despite all the radical transitions the continuities relating to the hereditary classical legitimate authority have been identified. In this context it has been manifested that the political modernization had preferred a way which had tended to preserve the essentials of the classical political culture. Thus it has been asserted that the political elites of the empire who had being governed on a multi-lingual and multifaith social structure had responded any crisis for protecting the unity with traditional reflexes. As a
\end{abstract}

\footnotetext{
* Dr. Öğr. Üyesi, Tarsus Üniversitesi, İ̇BF, Siyaset Bilimi ve Kamu Yönetimi Bölümü,
} ORCID ID: 0000-0002-7215-1073 halilkanadikirik@tarsus.edu.tr 
result it has been aimed to manifest a new patrimonial regime, with its all discrepancies in this time, could had been established again in a serious crisis moment although the authority had been spread among the bureaucracy in Tanzimat Era.

Keywords: Legitimacy, Modernization, Political Culture, Tanzimat, Tradition. JEL Codes: F54, H19, H82, H83, H89, P26, P41, P49.

\section{GíRiş}

Tanzimat Devri (1839 - 1876), Türkiye’nin siyasal modernleşme tarihinde kurumsallaşmanın sağlanması açısından yapı taşı niteliğini haiz bir zaman kesitini ifade etmiştir. Weber'in yasal-ussal meşruiyet tipine özgü bürokrasinin bu dönemde örgütlendiği ve takip eden dönemlerde de Türk kamu idaresini etkin şekilde yürüttügü bilinmektedir. Erkler ayrımına ve idarede laik teşkilatlanmaya ilişkin belirli bir mefhum da bu devirde oluşmaya başlamıştır. Bununla beraber söz konusu siyasal sistem klasik-patrimonyal imparatorluk yapısından tevarüs edilmiştir. Dolayısıyla tüm kökten modernleşme hamlelerine karşın, sorunların çözümüne yönelik geleneksel tavır alma alışkanlarını da modern kurumsallaşmasına taşımıştır. Bu ise siyasal kültür çalışmaları açısından değişim içindeki süreklilik unsurlarını ifade etmiştir. Söz konusu sürekliliklerin kaynağı, yine siyasal kültür çalışmalarında, siyasal aktörlerin herhangi bir duruma doğrudan değil de geçmiş "yönelimleri” (orientations) vasıtasıyla verdikleri karşılık anlamına gelen "yöneltilmiş eylem"dir (oriented action) (Eckstein, 1988: 790). Pierre Bourdieu'nun (1990: 54; 1995: 82) kültürel yeniden-üretim sürecine ilişkin olarak kavramlaştırdığ1 "habitus" da bu sürekliliklerin mantığını ortaya koymaktadır. Buna göre bir kültür alanını paylaşan aktörlerin sorun çözmeye yönelik geçmiş deneyimleri, güncel eğilimlerini de belirlemekte, değişimin meşruiyet sınırlarını çizmektedir. Türk modernleşmesi ve siyasal seçkinleri söz konusu olduğunda habitus, yöneten ile yönetilen arasındaki ilişkinin geleneksel-patrimonyal niteliklerini sarsmadan toplumsal kurumların radikal biçimde dönüştürülmesini ifade etmiştir. Bu makalede, öncesi ve sonrasıyla Tanzimat Devri, söz konusu kavramsal çerçevede ve yer yer benzer siyasal yapılarla karşılaştırmalar yapılmak suretiyle ele alınmak istenmektedir.

\section{TANZIMMAT ÖNCESİ: SIYYASAL MODERNLEŞMENIN YÖNÜ}

Osmanlı İmparatorluğu, hemen sınırında yer alması nedeniyle modernleşen dünya ile her zaman doğrudan temas hâlinde olmuştur. Karlofça Antlaşması'ndan (1699) beri hem uluslararası ilişkiler sisteminde hem de bazı askerî teknolojilerde Orta ve Batı Avrupa'ya intibak etmekte gecikmemiştir. Bununla beraber Batılı siyasal kurumların idareye uyarlanması tartışma konusu edilmemiştir (Ortaylı, 2010: 393-394). Siyasal otoritenin ve kurumlarının modernleşme ihtiyacını hissetmesi ve bu yönde harekete geçmesi için 18. yüzyılın son çeyreği ile 19. yüzyılın ilk çeyreğini beklemek gerekmiştir. Yaklaşık 
olarak bu tarihlerden itibaren siyasal otorite, daha evvel emsali görülmemiş bir yıkıma tabi tutulduğunu anlamaya başlar. 1774’te başlayan Kırım’ın elden çıkışı süreci 1792'de tamamlanmış ve ilk defa olarak Osmanlı’ya bağlı bir Müslüman ülke gayrimüslim bir devlet (Rusya) tarafından ele geçirilmiştir. Ancak modern tehdit kendisini daha çok ulusal isyanlarla ve nihayet Napolyon'un emperyalist amaçlarla Mısır’ı işgal etmesiyle (1798 1801) hissettirir hâle gelmiştir. Klasik Osmanlı siyasal otoritesi için bir tür varlık sebebi (raison dêtre) olan Balkan toprakları üzerindeki hâkimiyeti, Sırpların ve Yunanların isyanları ile sarsılmıştır. Ortadoğu'da ise çok uzun süren Vehhabî ayaklanması (1801 - 1820), özellikle hac yolunun asayişini sağlamakla mükellef Osmanlı hükümdarının otoritesini bir hayli zedelemiştir. Neticede jeopolitik ve siyasal kültür açısından Osmanlı egemenliği nezdinde ve yaklaşık iki bin yıldır siyasal varlığını devam ettiren Roma İmparatorluğu, tarihinde ilk defa modern tasfiye süreciyle yüz yüze gelmiştir.

Osmanlı siyasal otoritesinin bu süreçte aldığı ilk tedbir, meşveret meclislerini devreye sokmak olmuştur. I. Abdülhamid ve III. Selim dönemlerinde, padişahın başkanlığında üst düzey devlet adamlarıyla düzenli olarak toplanmaya başlayan bu meclislerde ele alınan siyasal meseleler her yönüyle tartışılmış, kararların oybirliği ile alınmasına özen gösterilmiştir (Akyıldız, 2015: 35). Böylece patrimonyal hükümdar kararlarının kendisine yüklediği sorumluluğu yaymak ve meşruiyetini artırmak için otoritesini merkezdeki memurlarla paylaşmaya başlamıştır (Akyıldız, 2015: 32). Meşveret meclisleri, geleceğin Bâbıalî bürokrasisi ve kanun yapan meclisleri açısından bir başlangıç sayılmalıdır. Zira klasik patrimonyalizmin dünyanın yeni durumunda pek de işlevsel olamayacağının ve modern yapılara aktarılması gerektiğinin anlaşıldığına dair bir işarettir.

III. Selim, 1slahat hareketini "modernleşmeye" ilişkin bir bilinçle başlatan ilk hükümdar olarak kabul edilebilir. Zira yeni kurduğu orduya "Nizam-1 Cedid" (Yeni Düzen) adını vermiştir ki bu isim Büyük Petrónun streltsi birliklerini ortadan kaldırdıktan sonra kurduğu modern orduya verdiği isim olan Noviy Stroy (Ortaylı, 2004: 38) ve Fransiz devrimcilerinin kendi siyasal sistemlerini geçmişten ayırdıklarını ifade eden Nouvel Ordre (Akşin, 1994: 7) terimi ile aynı anlama gelmektedir. Nizam-1 Cedid, dar anlamıyla askerî modernleşme çabasını ifade ederken geniş anlamıyla "yeniçerileri kaldırmak, ulemanın nüfuzunu kırmak, Osmanlı devletini Avrupa’nın ilim, sanat, ziraat, ticaret ve medeniyette yaptığı ilerlemelere ortak yapmak için” girişilen tüm modernleşme sürecini ifade etmiştir (Karal, 2017: 61). Selim, hareketine geleneksel bürokrasi nezdinde meşruiyet sağlamak için öncelikle merkezdeki 22 ileri gelen devlet adamından siyasal sorunların çözümüne ilişkin lâyihalar almış (Çağman, 2010), bunlar içinden muhafazakâr önerileri eledikten sonra kalanlarıyla Nizam-1 Cedid’e ilişkin bir program oluşturmuştur (Karal, 2017: 6264). Padişah bu programı uygulamaya soktuysa da kısa sürede geleneksel ayak direme ile karşılaşmıştır. 1807'deki yeniçeri ayaklanması III. Selim idaresini sona erdirmiş ve sabık padişahın bir yıl sonraki katliyle sonuçlanmıştır. İstanbul'u ele geçirerek isyancıları bertaraf eden reform yanlısı Rusçuk âyânı Alemdar Mustafa Paşa'nın II. Mahmud'u tahta çıkarmasının ardından ise ülkenin çeşitli bölgelerinden İstanbul’a gelen âyânlar ile padişah arasında Sened-i İttifak denilen bir sözleşme yapılmıștır. Gerek söz konusu geleneksel ayak direyiş gerek reformcu da olsa merkezi baskı altına alan çevre seçkinlerinin hâkimiyetine 
karşın Osmanlı siyasal otoritesi, Nizam-ı Cedid ile beraber sorunların çözümüne ilişkin merkeziyetçi bir modernleşme programına sahip olmuştur. Niyazi Berkes’e (2017: 169) göre bu programın da işin içine katılmasıyla beraber Türkiye’nin izleyeceği rotaya ilişkin üç yol ortaya çıkmıştır: "1) Şeriata dayalı bir İslâm devleti kurmak, 2) Merkeziyetçi hükümdarlık örgütü ile taşra güçleri arasında sözleşmeye dayalı bir devlet kurmak, 3) hükümdarın mutlak egemenliği altında merkeziyetçi bir bürokrasi monarşisi kurmak”. Berkes (2017: 169), bu üç eğilimin de Cumhuriyet dönemine kadar beraber var olabildiğini, siyasal otoritenin zaman zaman bunlardan birini öne çıkarttığını söyler. Ancak gelişmeler siyasal otoritenin, ilk iki eğilimin varlığına tahammül gösterse de üçüncü eğilimi kendisine yol olarak seçtiğini göstermektedir.

Sened-i İttifak, asıl nüshası dahi ortadan kaldırılmış (aktarıma dayanan bir tam metni için bkz. Akyıldız, 1998: 215-222), kimi yazarlara göre bir tür Magna Carta’dır. Ancak Magna Carta ile benzer iddialara sahip olsa da tezat sonuçlar doğurmuştur. Zira bu metin, II. Mahmud ve merkezin siyasal seçkinleri tarafından "pâdişahlı̆̆ın hak ve selâhiyetlerine aykırı” görülmüş ve bunun mimarı olan Alemdar Mustafa Paşa'ya karşı daima kin beslenmiştir (Karal, 2017: 93). Ayrıca Osmanlı âyânı, Batı tipi feodal lorda benzememektedir. Bunlar elde ettikleri mütesellimliklerle tarımsal artı-ürünü devlet adına toplarken bir kısmına el koyan, hiçbir tarımsal veya sınaî üretime dayanmayan memur-benzeri gruplardır. Zaten merkezî müsadereye tabi olan ve merkez tarafindan doğrudan tehdit edilip idam edilebilen feodal lord olamaz. Çağlar Keyder (2015: 27-28) bu grubun feodaliteyi kurumsallaştırabilecek bir sınıf olarak gelişip serpilememesini, ellerindeki tüm iktisadî imkânlara rağmen siyasal araçlara sahip olamamalarına bağlar. Oysa âyânlık üzerine arşivlerle desteklenen çalışmasında Yuzo Nagata’ya (1997) göre bu sınıfın ortadan kalkışı, daha çok dünya ekonomisi ile bütünleşen Osmanlı coğrafyasında ham madde tedarikçisi olarak büyüyen ticaret burjuvazisi karşısındaki gerileyişiyle ilgili olmuştur. Bu dahi âyânların herhangi bir üretim ve ticaret faaliyetine dayanmadıklarını ve neticede II. Mahmud siyasal otoritesini sağlam bir zemine oturttuğunda kolaylıkla tasfiye edilebildiklerini gösterir. II. Mahmud, Berkes’in belirttiği yollardan üçüncüsünü seçmiştir ki bu yol Türk modernleşmesine, merkeziyetçi devlet inşasına ağırlık veren karakterini kazandırmıştır. Bu yolun seçilmesindeki saik, siyasal otoritenin habitus'u olan patrimonyalizm ile yakından ilgili olmalıdır. Zira patrimonyal bir hükümdarın ilk iki yolu, birincisinde ulemanın, ikincisinde çevre seçkinlerinin sürekli müdahalesine maruz kalacağından otoritesine bir tehdit olarak algılayacağı açıktır.

II. Mahmud dönemi (1808 - 1839), Türk siyasal modernleşmesinin ne yönde seyredeceğini belirlemesi açısından önemlidir. Alemdar'ın da ortadan kaldırıldığı isyanda - ki padişah buna göz yummuştur - Osmanlı hanedanının artık kulları gözünde patrimonyal meşruiyete sahip olmadığı da ortaya çıkmıştır. Zira isyancılar, Mahmud'u katletmeleri hâlinde başka erkek üyesi kalmayan hanedanın da sona ereceği kendilerine hatırlatıldığında, onun yerine kız kardeşi Esma Sultan'ı, Konyadaki Mevlana soyundan (Çelebi) şeyhi ya da Kırım hanzadelerinden birini geçirebileceklerini ileri sürmüşler ve "Padişah bir insan değil midir? Kim olursa padişah olur. Yeter ki bizim ocağımız devam etsün”, demişlerdir (Karal, 2017: 96). Böylece padişah, geleneksel siyasal otoritesinin 
bu geleneksel askerlere dayanılarak sürdürülemeyeceğini görmüștür. Yine bu dönemde İngiltere, Fransa ve Rusya’nın desteklediği Yunan isyanının (1821 - 1829) ulusal devlet kurulması ile sonuçlanması, artık sadece Osmanlılar için değil, tüm Avrupa için geleneksel siyasî dengenin sürdürülemeyeceğini göstermiştir. Ayrıca Mısır'da Kavalalı Mehmed Ali Paşa’nın yürüttüğü modernleşmenin bu eyaleti birçok açıdan kalkındırması ve hatta payitahta meydan okuyacak düzeye getirmesi de II. Mahmud'un merkeziyetçi bir modernleşme programını uygulamaya koyması için hem bir örnek hem de bir baskı unsuru olmuştur. Tüm bu kriz ortamında padişahın yeniçerileri ortadan kaldırılması (1826), Türk siyasal hayatında modernleşmenin zembereğinden boşalmış gibi hızla seyrettiği bir süreci başlatmıştır. Modernleşmeye başlamadan önce siyasal otoriteye ayak bağı olan geleneksel askerî kurumun lağvedilmesine bu tarihten önce Rusya'da Büyük Petro'nun streltsi'yi şiddetle ortadan kaldırmasında, bu tarihten sonra da Japon siyasal otoritesinin samuray'ı daha az şiddetle tasfiye etmesinde de rastlanır. Bu devletlerin üçü de patrimonyal imparatorluklar olduğuna göre, patrimonyal siyasal otoritelerin modernleşmeyi başlatmak için her şeyden önce kendi geleneksel hizmet sınıflarını gözden çıkartmak zorunda kaldıkları görülür. Bunun yerine koyacakları yapılar da oldukça benzer niteliklere sahiptir. Öncelikle saraya karşı belirli bir özerkliğe sahip yeni bir hükümet tipinin oluşması, eğitimin giderek merkezîleşmesi, dinî otoritenin de din adamlarının kişiliğinden ayrışıp merkezî devlet kurumlarına devredilmesi bunlar arasındadır.

II. Mahmud'un hükümet sisteminde yaptığ 1 reform, kabine sisteminin kurulması ve geleneksel sadrazamlık makamının yetki ve sorumluluğunun tüm kabine üyeleri arasında paylaştırılmasıdır. 1838'de yaptığ 1 düzenlemeyle başvekâlet ismini alan sadrazamlığın, bundan böyle herhangi bir nazıra ek bir görev olarak verilmesi kararlaştırılmıştır ki ilk başvekil olarak, dâhiliye nazırı da olan Mehmed Rauf Paşa atanmıştır (Akyıldız, 2015: 46). Bu arada Mahmud, çeşitli konularda özelleşmiş meclisler kurarak ("Dâr-1 Şûra-yı Askerî", "Meclis-i Vâlâ-yı Ahkâm-1 Adliye”, "Dâr-1 Şûra-yı Bâbıâlî" gibi) devlet yönetimine danışma düzeyinde de olsa destek sağlayacak modern kurumları ihdas etmiştir (Karal, 2017: 153). Bu sistem o kadar kısa sürede yerleşik hâle gelmiştir ki 1839'da Mahmud'un ölümüyle başvekâlet mührünü ele geçiren muhafazakâr Hüsrev Paşa sadrazamlık makamını tekrar ihdas etse de bundan böyle sadrazamlık ismen yaşamaya devam etmiş, geleneksel üstün yetkilerine tekrar kavuşamamıştır. Artık daha çok nazırlar ve uzmanlaşmış meclisler arasındaki bir koordinasyon makamından ibarettir (Akyıldız, 2015: 47).

Şeyhülislâmlık makamı ve ulema da devletin merkezîleştirilmesi projesinden payına düşeni almıştır. II. Mahmud, ulema için önemli bir gelir kaynağı olan vakıfların gelirlerini ve idaresini, daha sonra müstakil bir nezarete dönüşecek olan Evkaf İdaresi’ne bağlamıştır. Böylece bu idare vakıfların ihtiyaç duyduğu masrafları yaptıktan sonra gelirin kalanını merkezî hazineye aktaracaktır. Ulemanın gücünü önemli ölçüde kıran söz konusu uygulama Mahmud hayattayken tam olarak başarıya ulaşamadıysa da kendisinden sonra zamanla yerleşik hâle gelmiştir (Lewis, 2017: 131-132). İran'da siyasal otoriteler bunun benzeri bir reformu hiçbir zaman gerçekleştirecek güce sahip olamadıklarından, ülkenin modern tarihi boyunca Şiî ulema, sahip olduğu bu önemli gelir tabanı sayesinde seküler siyasal otoritenin paralelinde bir otoriteyi kurumsallaştırabilmiştir. 
Yine ulemanın otoritesini belirli kurumlara bağlamaya yönelik bir diğer uygulama da Mahmud'un, eskiden yeniçeri ağasına ait olan binayı şeyhülislâma devretmesidir. $\mathrm{Bu}$ basit bir bina değişikliği değildir. Bundan önce şeyhülislâmlar, geleneksel idareciler de görüldüğü gibi kendi hanelerinde çalışmaktadırlar. Oysa Mahmud, onların hane ve iş yerlerini birbirinden ayırarak merkezî kurumsallaşma yönünde önemli bir adım atmıştır. Burada kurulan Bâb-1 Meşîhat ve Fetvahane, ulemanın bürokratikleşmesini sağlamıştır. Zamanla kurumsallaşma artmış, fetva verme işi de bir kişinin uhdesinde olmaktan çıkarılarak fetva emini başkanlığında bir hukukçular kuruluna devredilmiştir. Tanzimat döneminde öğretmen atamalarının maarif nezaretinin, kadı atamalarının da adliye nezaretinin yetkisine verilmesiyle şeyhülislâmlığın klasik işlevi budanmış ve kurum bir fetva makamı olarak varlığına devam etmiştir (Lewis, 2017: 136-137). HıristiyanOrtodoks dünyada dinî kurumun buna benzer bir bürokratikleştirilmesi süreci, bir yüzyıl önce Rusya'da I. Petro’nun, Patriklik makamını lağvedip yerine "Kutsal Sinod"u kurmasıyla başlamıştır.

$\mathrm{Bu}$ arada halkın dinî yaşantısında çok önemli bir yere sahip olan tarikatlar da söz konusu merkezîleşmeden etkilenmişlerdir. Bektaşî tarikatı yeniçerilerle özdeşleştiğinden merkezî otoritenin güvenini yitirmiş, yeniçeriliğin ilgası sürecinde kanlı bir takibata uğramıştır. Bektaşîlerden boşalan yere, tarikatlar üzerinde merkezî denetimi sağlamak üzere siyasal otorite tarafından Nakşibendilik ve Mevlevilik geçirilmiş, böylece bu tarikatlar belirli bir resmiyet alanına sahip olmuşlardır. 1866'da kurulan ve medrese uleması ile tarikat şeyhlerinden oluşan Meclis-i Meşâyih, zamanla merkezî denetim işlevini ele almıştır (Ortaylı, 2004: 138-139). Söz konusu denetimin dışına çıkan ve devletin üstüne aldığg işlere müdahil olmaya çalışan popüler dinî hareketler derhal zapturapt altına alınmıştır. Örneğin Kırım Savaşı esnasında (1853 - 1856) İstanbul'da cihad bayrağı açarak orduya gönüllü asker toplamaya çalışan bir Rufâî şeyhi, zabtiye nezareti ve seraskerlikçe engellenmiştir (Ortaylı, 2004: 139). Bütün bunlar devlet-din ilişkisinde tarihsel bir kırılmaya değil, bilâkis bir sürekliliğe işaret eder. Dinî kurumu hem denetim altında tutmayı hem de toplumla arasında bir bağ geliştirmek için ondan yararlanmayı amaçlayan sezaropapist sistemiyle patrimonyal siyasal otorite, söz konusu modern kurumsallaşmayı gerçekleştirirken de bu işlevin muhafaza edilmesine özen göstermiştir. İleride de görüleceği gibi ne dinî kurumun siyasete müdahil olmasına fırsat vermiş ne de bu kurumdan vazgeçebilmiştir.

II. Mahmud ile başlayan modern-merkezî devlet inşası, Batı'daki modelinin aksine şehirli ticarî sınıfların merkezle bir uzlaşısına dayanmamıştır. Burada siyasal otorite ile halk arasında demokratik temellere dayanan yeni bir tür ilişki tesis etme amacı yoktur. Tüm bu reformlar sadece, artık aşınmış olan klasik siyasal otoritenin yeniden ve bu defa modern kurumların yardımıyla tesis edilmesi planlanarak yapılmıştır (Karal, 2017: 143). Mahmud'un iç siyasetteki hedefi, geleneksel otoritesinin önünde engel olarak gördüğü tüm ara iktidar odaklarının, veraset, gelenek, halk desteği vb. hangi kaynağa dayanırsa dayansın derhal ortadan kaldırılmasıdır. Mısır sorunu hariç bu politikası oldukça başarılı sonuçlar vermiştir (Lewis, 2017: 125). Yine de Osmanlı modernleşmesi, Mahmud'un hiç beklemediği biçimde sonuçlanmış görünür. Zira kendisinden sonra uzunca bir süre devlet iktidarı, bizzat kurduğu Bâbıâli’nin eline geçmiştir. 


\section{TANZIMAT: OTORİTENIN BÜROKRATİKLEŞMESI}

İlber Ortaylı (2004: 89-90), Osmanlı İmparatorluğu’nun 1839 Gülhane Hatt-1 Hümayun'unun (Tanzimat Fermanı) ilânının ardından gelen dönemlerini üçe ayırır: 1) Tanzimat dönemi de denilen, sarayın dışında özerk bir yapı olan sadrazam ve nazırlardan oluşan "Bâbiâli diktatörleri”nin, yani hükümetin devletin idaresinde egemen olduğu dönem; 2) I. Meşrutiyet (1876 - 1877) sonrası Abdülhamid'in istibdat dönemi; 3) II. Meşrutiyet’ten (1908) sonra İttihat ve Terakki'nin modern parti diktatörlüğü. Dönemlerin tanımlanma biçiminden de anlaşılabileceği gibi Türkiye’nin siyasal modernleşmede izlediği yol, merkezde toplanan siyasal otoriteyi çevreyle paylaşmama esasına dayanmıştır. İşte Tanzimat döneminde bu yapılanmanın ana aktörleri, çoğu hariciye teşkilâtında yetişmiş sivil hükümet memurlarıdır. Tanzimat Fermanı'nın en acil getirisi ise hem bu memurların hem hanedan üyelerinin hem de tüm tebaanın can ve mal güvenliğini hükümdarın şahsî güvencesine değil, kanuna bağlamasıdır. Padişahın (Abdülmecid) kendisi de bu fermanda belirtilen ilkelere uyacağına dair yemin ederek kanunla bağlı olduğunu ortaya koymuştur (Karal, 2017: 193). Böylelikle Osmanlı İmparatorluğu anayasal bir sürecin içine girmiş, henüz temsilî kurumlara sahip olmadığından bir tür aydınlanmış despotizm rejimine geçiş yapmıştır.

Tanzimat Fermanı’nın mimarı olan Mustafa Reşid Paşa, özellikle söz konusu can ve mal güvenliği ilkesi üzerinde durmuş, idarenin bu konuyu ciddiye alması gerektiğini ilk aylardan göstermeye başlamıştır. Edirne Valisi, iki kişiyi keyfî olarak idama mahkûm etmekten yargılanmıştır (Engelhardt, 2017: 54). 1841'de Reşid Paşa'nın sadaret görevi sona erdiğinde Tanzimat Fermanı'nda belirtilen modernleşme programının da sona ereceği varsayılmışsa da böyle olmamış, yeni idarenin tavrı, özellikle maliyede merkezîleşme politikasıyla söz konusu programın sürdürüleceğini göstermiştir (Engelhardt, 2017: 77). Anayasalcı hassasiyet de aynen devam etmiştir. 1846'da memurların yetki ve sorumluluklarını belirleyen ve suiistimallerine ceza öngören idarî kanun yürürlüğe girer girmez, bu modernleşme hamlesini ciddiye almayarak buna karşı eylemlerde bulunan başta sabık sadrazamlardan Hüsrev Paşa olmak üzere birçok üst düzey devlet adamı, söz konusu kanun kapsamında yargılanıp çeşitli cezalara çarptırılmışlardır (Karal, 2017: 173174).

Tanzimat'ın Osmanlı siyasal sisteminde yerleşik hâle gelmesinin en önemli sonucu saray ile hükümetin kaçınılmaz ayrışması olmuştur. II. Mahmud, reformlarının bu noktaya varacağını kestirmiş olmalıdır. Zira Bâbıâli’ye çalışmalarını sürdüreceği yer olarak sarayın yanındaki Gülhane Kasrı’nı tahsis etmiştir (Akyıldız, 2015: 166). Ancak Bâbıâli zamanla saraydan fiziksel olarak da uzaklaşacaktır. Abdülmecid döneminde (1839 - 1861) saray, Meclis-i Vâlẩnın yaptığı kanunların ve Bâbıâli'nin yürütmesinin sadece bir onay mercii işlevi görmüştür. II. Mahmud döneminde padişahın reformlarını (Tanzimat-ı Hayriyye) yürütmek üzere kurulan "Meclis-i Vâlâ-yı Ahkâm-1 Adliye", Tanzimat Fermanı’ndan sonra bir tür yasama, yürütme ve idarî yargı merciine dönüşmüştür (Seyitdanlıoğlu, 1999: 41). 1868'e kadar çeşitli idarî değişimlere uğrasa da bu vazifesine devam edecektir. 1840 'ta Bâbıâli'deki müstakil binasına taşınması dolayısıyla yapılan açılışa padişah bizzat 
katılmış ve nutku meclise Reşid Paşa tarafından okunmuştur. Bundan sonra tıpkı meşrutî monarşilerde görüldüğü gibi, padişahın her sene meclisin açılışına bizzat katılarak yapılan ve yapılacak işler hakkındaki nutkunu okutması bir gelenek hâline gelmiştir (Seyitdanlıŏ̆lu, 1999: 45). Hukukî açıdan Meclis-i Vâlâ, padişahın mutlak kararlarına destek olacak bir danışma meclisi olsa da Tanzimat döneminin kanunlarını üreten asıl mercii olmuştur. Zira padişahın mutlak egemenliği artık daha sembolik bir seviyede kalırken, bu meclisin aldığı kararların hemen hepsi padişahlıkça onaylanmıştır (Seyitdanlıŏ̆lu, 1999: 129).

Tanzimat döneminde bu meclisin işlevsel ayrımlara tabi tutularak bölünmesi, Osmanlı siyasal düşüncesinde kuvvetler ayrımına ilişkin bir mefhuma ulaşıldığını gösterir. 1868'de Meclis-i Vâlâ iki ayrı meclise bölünerek ömrünü tamamlamıştır. Bu meclislerden biri yasama ve idarî yargı işlerini üzerine alan, Roderic Davison’ın (1997b: 13) "embriyon halindeki bir parlamento" olarak tanımladığı Şûrâ-yı Devlet'tir. Öteki meclis ise şer’î mahkemeler ve gayrimüslim cemaatlerin mahkemeleri dışında kalan sivil yargılama işlerini üzerine alan Divân-1 Ahkâm-1 Adliye'dir. Bunların açılış konuşmasını yapan Sultan Abdülaziz, söz konusu konuşmasında kuvvetler ayrımının önemine değinmiştir. Padişah, "hükümet-i şer'iyye ve kavânîyyenin hükümet-i icrâiyyeden tefriki esâsı vaz" olunduğunu söyler (Seyitdanlığlu, 1999: 115).

Tanzimat ile devletin idaresini ele alan Bâbıâli bürokrasisinin hedefi, tıpkı II. Mahmud'un reform hedeflerinde söylendiği gibi, devletle halk arasında yeni bir ilişki biçimini tesis etmek değil, devletin parçalanmasını önlemektir. Reşid Paşa ve ardından onun yetiştirmeleri olan Mehmed Emin Âli, Keçecizade Fuad, Ahmed Cevdet ve Ahmed Vefik paşalar gibi devlet adamlarının siyasal modernleşmede takip ettikleri yön de bu olmuştur. Tanzimatçların ideolojisinin bir tarafı Fransız tipi merkeziyetçi devlettir. Zira aynı dönemde örnek alabilecekleri diğer model, İngiliz tipi adem-i merkeziyetçilik olabilirdi ki bunu seçmeleri hâlinde keskin ve tepeden inmeci reformlara girişemeyecekleri açıtır (Ortaylı, 2004: 140141). Tanzimatçı devlet adamının seçtiği yol kendisine, tebaayı yönetmek için en doğru politikaların yegâne belirleyicisi olma ayrıcalığını (hikmet-i hükümet) veren ve tepeden inmeciliğine meşruiyet kazandıran patrimonyal kültürel kodlarına en uygun olanıdır. Dahası bu tarz bir oryantasyon, pozitivizmin ünlü kuramcısı August Comte'un bile takdirini kazanmıştır (Sivayuşgil, 1940: 755) Türkiye'de yerel yönetimler dahi, Batı Avrupa örneğinin aksine bu merkeziyetçilik zemini üzerinde kurulmuştur. Klasik dönemden beri özerk idareye sahip Hicaz ve Yemen gibi vilâyetlere ek olarak modern dönemde özerklik kazanan Cebel-i Lübnan, Bosna-Hersek, Misır, Girit ve Sisam adaları haricinde kalan tüm Osmanlı topraklarında merkezî idareye bağlı vilâyetler ve bunlara bağlı sancaklar teşkil edilmiştir (Ortayl1, 2000: 63-69). Bu reformun amac1, o zamana kadar kendi idarî bölgelerinde adeta birer küçük hükümdar gibi hareket eden ve mültezimlerden geçinen valileri ve diğer görevlileri, kendilerine hazineden düzenli maaş ödenen merkezin memurları konumuna sokmaktır (Engelhardt, 2017: 107). Bundan sonra geleneksel dönemin güçlü valileri görülmez. Valiler ile askerî komutanın yetkileri ayrıştırılmış, 1871'de yayımlanan nizamname ile de vilâyet idare meclisleri kurularak idarî soruşturma ve vergi uyuşmazlıkları gibi konuları çözme görevi bunlara verilmiştir (Ortaylı, 2000: 70, 72). Bu sayede yerel yönetimler, merkeziyetçi bir tarzda modernleşmiştir. 
Tanzimat ideolojisinin bir diğer tarafı ise Avusturya tarzı Kaiserreich nationalismus'un bir benzeri olan Osmanlıcılıktır ki bu da tebaayı parçalamadan bir arada tutmanın yolu olarak görülmüş, ancak yönetici seçkinlerin ideolojisi olmaktan öteye geçememiştir (Ortaylı, 2004: 113). Daha en başında Tanzimat Fermanı okunurken hazirundan Rum Patriği, fermanda ima edilen tüm tebaanın din farkı gözetilmeksizin eşitliği ilkesinden hiç hoşlanmadığını belli etmiştir. Zira Rumların diğer Hıristiyan veya Yahudi tebaaya göre devlet nezdinde daha fazla imtiyazı vardır ve Tanzimat bu statülerini tehdit etmektedir (Karal, 2017: 187). 1856'da, Osmanlı İmparatorluğu’nun Batı Avrupalı müttefiklerinin baskısıyla ilân ettiği Islahat Fermanı, bu eşitliğe resmiyet kazandırmıştır. Ancak merkezî idare, yine en başta Rumlar olmak üzere gayrimüslim tebaanın tepkisi ile karşılaşmıştır. Bu eşitlik Hıristiyanlar için o güne kadar muaf oldukları askerlik vazifesini şart koşarken, özellikle Rumlar için, Osmanlı millet sisteminde hiyerarşik olarak altlarında yer alan Yahudilerle kendilerini eşit statüye getirdiğinden kabul edilmesi zor bir reform olmuştur. Rumlar sık sık, bunu kabul etmektense İslâm üstünlügüne razı olduklarını beyan etmişlerdir (Küçük, 1994: 20). Islahat Fermanı uyarınca yapılan bir takım düzenlemeler de bu cemaatler arasında laikliğin etkinlik kazanmasıyla sonuçlandığından, bunlar arasındaki geleneksel çıkar sahiplerine zarar vermiştir. 1862 - 65 arasında Rum Ortodoks, Gregoryen Ermeni ve Yahudi uyruklular için çıkarılan bazı kanunlar ile bu milletlerin işlerinde laik kişilerin etkin olduğu meclislere yetki verilmiştir (Davison, 1997a: 137138). Bu ise o güne kadar makam satışı ile gelir elde eden ve kendi kilisesine bağlı olan Bulgarları sömüren Rum patrikliğinin ve memurlarla bir olup Ermeni köylüleri sömüren Ermeni ileri gelenlerinin (çorbacılar) işine gelmemiştir (Davison, 1997a: 139-140).

Islahat Fermanı, Avrupa devletlerinin baskısına boğun eğerek bunu onaylayan Âli ve Fuad paşaların tüm çabalarına rağmen hiçbir tarafı memnun etmemiştir. Özellikle 1860 'lı yıllar boyunca yapılan reformları yeterli görmeyen yabancı devletlerin Osmanlı iç siyasetine müdahale etmesine imkân vermiştir. Ayrıca Balkanların parçalanmasını bekleyen Rusya’yı da durduramamıştır. Rusya tarafının beklentisi, İstanbul'daki sefiri General İgnatyev indinde gayet açıtır: "Ou autonomie ou anatomie" (Ya otonomi ya anatomi) (Engelhardt, 2017: 224)! Rusya ve Avusturya, Balkanlar'daki çıkarlarından dolayı Osmanlı reformlarının başarıya ulaşmaması için çaba sarf etmişlerdir. Örneğin, bugünkü Bulgaristan’n büyük bölümünü kapsayan Tuna Vilâyeti’nin Midhat Paşa’nın valiliği döneminde, sadece 3,5 yılda büyük bir modernleşme ve kalkınma başarısı göstermesi, paşanın sadece içerideki değil, dışarıdaki düşmanları tarafından da türlü şikâyetlere maruz kalmasına ve Şûrâ-yı Devlet başkanlığına atama bahanesiyle merkeze çekilmesine neden olmuştur (Ortaylı, 2000: 56-61). General İgnatyev'in 1872'de, Viyana'daki Rus sefirine yazdiğ1 mektupta da Tuna Valiliği'nden bu yana Midhat Paşa'nın Rusya'ya yönelik hasmane tutumundan bahsedilmekte, paşanın Rusya’nın Rumlar ile Bulgarları ayırmaya yönelik (Bulgarlar 1870 'te bağımsız Bulgar Kilisesi kurulana kadar Rum Ortodoks Kilisesi’ne bağlıdırlar) politikası önünde büyük bir engel olduğundan şikâyet edilmektedir (Durmaz, 1997: 58$59)$.

Tüm aksaklıklarına rağmen Tanzimat Dönemi, Weber’in tanımladığı biçimiyle modern bürokrasinin Türk idare sisteminde yerleşmesini sağlamıştır. Bundan kuşkusuz saray ile 
hükümetin ayrışmasının büyük rolü olmuştur. Zira klasik patrimonyal otorite anlayışının aksine artık tek bir kişi tüm otoriteyi üstlenmemekte, söz konusu otorite kurumlara yayılmaktadır. Merkezde padişahın ve sadrazamın otoritesi kabineye ve meclislere, çevrede ise valininki defterdar ve ordu komutanına yayılmıştır. Laik hukuk ve eğitim başlamış, modern ordu tesis edilmiştir. Ulema zayıflarken, basının ortaya çıkışıyla ideoloji üreten alternatif toplumsal kanallar ortaya çıkmıştır. Neticede devlet ve toplum artık tek elde toplanan bir otorite ile yönetilemeyecek düzeye gelmiştir (Ortaylı, 2004: 92). Bütün bu modern yapılanmaya karşın patrimonyalizm de alttan alta kendini hissettirir. Yönetici sınıf hâlen merkezde toplanan, meşruiyetini dar bir üst sınıfa mensup olmasından alan memurlardır. Berkes'e (2017: 205-206) göre bu dönemde bürokrasi modernleşmişse de klasik kul sisteminin yerini klientalizm ve patronaj ağları almıştır. Servet elde etmenin yolu hâlen devlete kapılanmaktır. Modern kurumların Batı tipi eğitim almış bürokratların icraatlarında ve düşünüşlerinde havass-avam arasındaki ilişkinin geleneksel nitelikleri pek değişiklik göstermemiştir.

\section{ANAYASAL REJIME DOĞRU}

Siyasal modernleşme, siyasal meseleler hakkında karar sürecine katılmak isteyenlerin sayısını kaçınılmaz olarak arttırmıştır. Bu katılma talepleri Türk siyasal hayatında ilk defa Tanzimat Dönemi basın-yayın faaliyetleriyle kendini göstermiştir. Habermas'ın (2015: 96-102) Batıdaki modernleşme sürecinde bu tarz öncü faaliyetler için kullandı̆̆ tabir ile söylenecek olursa Osmanlı İmparatorluğu'nda bir tür "edebî kamusallık” yaşanmaya başlamıştır. Ancak Habermas’in Batı Avrupa’da gözlemlediğinin aksine bu kamusallık, burjuva taleplerinin siyasal topluma taşınmasıyla devam etmemiştir. Bu kamusallaşmanın taşıyıcıları, genellikle Batılı modern kavramlardan etkilenen devletin kendi memurlarıdır. Bunlar gazete ve dergilerle bu kavramları Türkiye'ye tanıtmışlardır. Şinasi, gazetesi Tasvir-i Efkâr’da "ulus”un temsilcisi olarak "devlet” fikrini işlemesi ve ifade özgürlüğüne ilişkin makaleler kaleme almasıyla bu konuda öncü bir role sahip olmuştur (Çavdar, 2004: 30). İstanbul'da yayın yapan yabancı basın da rejimin niteliğini tartışmaya açarak eğitimli Türk bürokratları için adeta bir okul vazifesi görmüştür. Mazzini-Garibaldi devrimcilerinden olan ve İstanbul'da mülteci olarak bulunan Gianpietri'nin Courrier D'orient gazetesinde başlattığı ve daha sonra payitahttaki diğer yabancı gazetelerin de katıldığı anayasa tartışması, Türk enetelijansiyasının meşrutî bir rejime ilişkin fikirlerinin oluşumuna önemli bir katkı sağlamıştır (Çavdar, 2004: 32). 1856 ile 1876 arası dönemde oluşmaya başlayan bu yeni tip Türk entelektüeli için "kamuoyu" (efkâr-1 umumiye) giderek önem kazanan bir kavram hâline gelmiştir. Bu kamuoyu, "en eski Müslüman geleneklerinden en yeni Parisli seküler düşünceye kadar uzanan, birbiriyle çatışan ve çakışan etkilerin” bir ürünüdür ve 1876'ya gelindiğinde Türk siyasal hayatında hesaba katılması gereken bir unsurdur (Davison, 1997a: 20).

Daha çok kendileri gibi devlet memurlarına hitap eden bu entelektüellerin oluşturduğu 1860'ların muhalif grubu Yeni Osmanlılar olarak anılmaktadır. Yeni Osmanlılar hareketi 
tutarlı bir ideolojiyi temsil etmekten ziyade, tek ortak noktaları dönemin sadrazamı Âli Paşa’yı devirme isteği olan entelektüellerin genel adıdır (Davison, 1997a: 200-201). Bunların bir kısmı 1865’te Belgrad Ormanları’nda buluşarak “İttifak-1 Hamiyet” (sonradan "Yeni Osmanlılar") adında gizli bir cemiyet kurmuşlardır. Namık Kemal aracılığıyla veliaht şehzade Murad ile de temas hâlinde olan grup, 19. yüzyılda Avrupa'da kurulan modern devrimci yer altı örgütlerinin hemen hepsi gibi İtalyan devrimci Carbonari örgütünü model alan hücre biçimli örgütlenmeye sahiptir. Örgütün finansörü ise Mısır'daki hıdivlik makamının veliahtlı̆̆ını yaş farkı nedeniyle ağabeyine kaptırmaktan dolayı muzdarip olan Mustafa Fazıl Paşa'dır. Amaçları Âli ve Fuad paşaları, gerekirse Sultan Abdülaziz’i devirmek ve meşrutiyeti ilân etmektir.

Mehmed Emin Âli ve Keçecizade Fuad paşalar, yukarıda da değinilen Bâbıâli diktatörlüğünün dümenini ellerinde tutan iki isimdir. 1850'lerden Fuad'ın öldüğü 1869'a ve Âli'nin öldüğ̈̈ 1871'e kadar, kendi aralarında sadrazamlık ve hariciye nazırlığını paylaşan bu ikili, Osmanlı modernleşmesinin taşıyıcıları olmuşlardır (bkz. Acar, 2020). Muhaliflerince "günü kurtarmak" fikriyle ve "après moi, le déluge" (benden sonra tufan) ilkesiyle hareket etmekle itham edilmişlerdir (Davison, 1997a: 103). Ancak siyasetlerinin ana fikri Avrupalı devlerin müdahalesini mümkün olduğunca önlemek, devletin bütünlügünü korumak ve bu arada da idarî reformlarını sonuçlandırmaktır (Engelhardt, 2017: 245). Muhaliflerin hedefindeki, sadece yurtiçinde değil, tüm Avrupa diplomatik çevrelerinde nüktedan karakteriyle tanınan Fuad Paşa'dan çok, hükümetin idaresine yetkisiz kişilerin karışmasından hiç hoşlanmayan ve meşrutiyet fikrine şiddetle karşı olan Âli Paşa'dır.

Kamuoyuna tanıttıkları tüm Batılı siyasal fikir ve kavramlara rağmen Yeni Osmanlıların muhalefeti, Bâbıâli'nin modernleşme biçimine karşıdır. İleri sürdükleri argümanların çerçevesini İslâm hukuku oluşturmuştur. Bernard Lewis (2010), Müslüman dünyada modern siyasal kavramların İslâmî bir çerçeve içinde yeniden üretildiğini vurgulamıştır. Örneğin Yeni Osmanlıların siyasal bir kavram olarak kamuoyuna tanıttıkları "hürriyet”in geleneksel İslâmî toplumda sadece hukukî bir karşılığ vardır ki o da kölelik durumunun zıttını ifade etmiştir. Lewis (2010: 78), “Geleneksel Müslümanlar için tiranlığın karşıtı özgürlük değil adaletti” der. Yeni Osmanlılar da Bâbiâli’ye muhalefetlerini bu temelde çeşitlendirmişlerdir. Onlara göre Âli ve Fuad paşalar yabancı devletlere sürekli taviz vermekte, şeriatı dikkate almamakta, "sı̆̆ bir laisizm" sergilemektedirler. Tanzimat'ın ikili hukuku yerine şeriat tam olarak uygulanmalıdır. Örneğin Namık Kemal, şeriatın "şûra" ve "usul-u meşveret" ilkelerini ileri sürmüş ve bu doğrultuda anayasal bir rejimi savunmuştur (Lewis, 2010: 236; ayrıca konunun şeriat çerçevesinde ele alınmasıyla ilgili olarak bkz. Gencer, 2009).

Grubun sürgündeki kanadı 1867'de harekete geçmiştir. Bu tarihte Mustafa Fazıl Paşa’nın Sultan Abdülaziz’e hitaben yazdığı açık mektup önce Fransa'da la Liberté gazetesinde, ardından Türkçe bir tercümesi de müstakil baskılar ile İstanbul'da yayımlanmıştır. Mektupta padişaha güncel siyasal sorunlardan bahsedilmekte, bunlara ilişkin çözüm önerileri sıralanmaktadır. Bu öneriler içerisinde Müslüman veya Hıristiyan tüm Osmanlı 
tebaasının eşitliğinin sağlanması ile meşrutiyet talebi de yer almaktadır (Buzpınar, 2006: 301). Özellikle "Hünkârım, İmparatorluğu kurtarınız, meşrutiyeti ilân ediniz" cümlesi dikkat çekicidir (Çavdar, 2004: 33). Aynı yıl Mustafa Fazıl Paşa, Namık Kemal, Ziya Paşa, Ali Suavi ve Agâh Efendi'nin de içinde olduğu Yeni Osmanlıların sürgündeki grubu, Paris'te bir Jön Türk parti tüzüğü hazırlamışlardır. Burada da mevcut idarecilerin ve rejimin değiştirilmesi talebi vardır (Davison, 1997a: 227).

Âli Paşa’nın 1871'deki ölümünden sonra siyasal denge, Bâbıâli aleyhine bozulmuştur. O güne kadar bu muktedir devlet adamının gölgesinde kalan Sultan Abdülaziz, bu boşluktan istifade ederek geleneksel bir hükümdar gibi davranmaya başlamıştır. Sarayın otoritesine gölge düşürmeyecek bir kişi olarak gördüğü Mahmud Nedim Paşa’yı sadrazamlığa atamıştır. Ne var ki otorite bir kere modern hükümet sistemine ve bürokrasiye yayıldıktan ve bu tarz idare yerleşik hâle geldikten sonra geleneksel hükümdar tipine geri dönmek krizden başka bir sonuç doğurmamıştır. 1871 ile 1876 arasındaki kötü yönetimin yanı sıra 1875'te hükümetin dış borç faizlerini bile ödeyemez hâle gelmesi, ayrıca 1873-74'te Anadolu’yu vuran kuraklık ve açlık nedeniyle kitlesel ölümler, Sultan Abdülaziz’in devrilmesine ve meşrutiyetin ilânına yol açan siyasal krizi doğurmuştur. Abdülaziz’in asker, sivil bürokrasi ve medrese talebelerinin ittifakıyla gerçekleşen hükümet darbesi neticesinde hal' edilmesinin ardından anayasa tartışmaları başlamıştır. Bununla beraber darbeyi yapanların kurulacak yeni rejimin niteliği konusunda ortak fikirlere sahip olmadıkları da kısa zamanda anlaşılır. Toplanan Meşveret Meclisi'nde Midhat Paşa ile askerî kanattan Süleyman Paşa’nın başını çektiği bir grup meşrutiyetin ilânını savunurken Sadrazam Mütercim Rüşdü Paşa ile yine askerî kanattan Hüseyin Avni Paşa’nın başını çektiği çoğunluk grubu ise buna karşı çıkmıştır. Meşrutî bir rejime muhalif olanların dayandığı argüman, içlerinden fetva emininin sözleriyle ifade edilecek olunursa devlet işlerinin nasıl yürütüleceğine ilişkin "birtakım cahil Türkler"den rey sormanın bu kriz ortamında hiçbir faydasının olmayacağıdır (Çavdar, 2004: 44). Bu arada gerçekleşen bir silahlı saldırı neticesinde ikinci kanadın liderlerinden Hüseyin Avni Paşa’nın katledilmesi üzerine Midhat Paşa, Namık Kemal ve Ziya Paşa grubunun eli rahatlamış ve emrivakiyle de olsa anayasa yapım sürecini başlatabilmişlerdir.

Kanun-1 Esasî, Midhat Paşa grubunun gerek iç gerek dış baskılara karşın bir an evvel ilân edilmesini arzuladıkları bir metindir. Onlar için bu o kadar acildir ki ruhsal buhranlar geçiren yeni padişahın (V. Murad) iyileşmesini bekleyemeyeceklerinden, kendilerine anayasa ilân edeceği teminatını veren veliaht şehzade Abdülhamid'i yerine geçirmek üzere, tahta geçişinden sadece 3 ay sonra onu da hal' etmişlerdir (1876). Bu dönemde Osmanlı hükümeti Avrupa devletleri tarafından malî iflas ve Bulgar ayaklanmasıyla ilgili reformlar yapmaya zorlanmaktadır. Hatta İstanbul'da bu konuda bir konferans toplanacak olup (Tersane Konferansı), hazırlıkları dahi tamamlanmak üzeredir. Midhat Paşa bu konferansta Osmanlı tarafının elini güçlendireceğinden meşrutiyetin bir an evvel ilân edilmesini istemektedir. Bu şartlar altında II. Abdülhamid ile yaptığı pazarlıkta öyle tavizler vermiştir ki ilân edilen anayasa bir diktatörlük için her türlü kanunî imkânı sağlamaktadır. Berkes'e göre Kanun-1 Esasî, temel anayasal nitelikleri haiz değildir. Parlamentoya yasa çıkarma yetkisi tanımamakta, hükümetin belirlenmesinde padişaha çok 
geniş yetkiler tanımakta, hükümeti denetleme mekanizmalarını zayıf tutmakta, padişaha meclisi feshetme yetkisi vermekteyken meclisin yeniden açılmasılyla ilgili herhangi bir zaman kısıtına gitmemektedir. Berkes (2017: 334-335), Abdülhamid'in istibdat rejiminin bu anayasaya tamamen uygun olduğunu söyler: "Abdülhamit'i Abdülhamit yapan bu Kanun-1 Esâsî̀dir”. Midhat Paşa’nın yargılanmaksızın sürgün edilmesine neden olan ünlü 113. Madde bile, anayasalcı liderlerin kendi fikirleriyle çelişen uygulamalarından doğmuş ve Abdülhamid'e altın tepside sunulmuştur. Şöyle ki; 1876'da Heyet-i Vükelâ anayasa taslağı üzerinde tartışırken bir grup anayasa muhalifi eylemler yapmış, bunların nezaretlere yönelik bazı komplolar hazırladıkları anlaşılmıştır. Konuyu Heyet-i Vükelâya getiren Midhat Paşa, bu kişilerin yargılanmaksızın derhal sürgün edilmelerini istemiş, hatta bunların formaliteden de olsa yargılanmalarını öneren Abdülhamid'i dahi istifa etmekle tehdit ederek dediğini yaptırmıştır. Namık Kemal de bu konuda Midhat Paşa'yı desteklemiştir. Böylece II. Abdülhamid kendisine verilen kozu değerlendirmiş, anayasayı ilân etmeden önce son dakikada bu fiilî durumu 113. Madde ile anayasaya koydurmuştur (Tunaya, 2016: 6-7).

$\mathrm{Bu}$ şartlar altında çalışmaya başlayan Meclis-i Mebusan, padişahın gölgesini sürekli üzerinde hissetmiştir. Abdülhamid'in meclisin onayını aramaksızın başkanlığına atadığı Ahmed Vefik Paşa, adeta geleneksel hükümdarın meclise bakışını yansıtmıştır. Meclis Başkanı oturumları yönetirken mebuslara karşı oldukça kaba bir tavır takınmış, hatta kürsüden onlara hakaret edebilmiştir (Çavdar, 2004: 48). Yine de meclis, Osmanlı siyasal hayatına ilişkin esaslı konuların tartışıldığı bir mecra olabilmiştir. Bu tartışmalardan biri, anayasal ve parlamentolu bir rejimde patrimonyal niteliklerin nasıl ağır bastığını göstermesi açısından burada özellikle zikredilmelidir. Tarık Zafer Tunaya’nın (2016: 7779) aktardığı söz konusu tartışma mebuslardan Teodor Kasap Efendi ile Ahmed Midhat Efendi arasında cereyan etmiştir. İki dereceli sistemi öngören anayasaya göre mebusları doğrudan halk seçmemekte, ikinci dereceli seçmen olan bürokratlar seçmektedir. Kasap bu konuyu meclise taşımış ve halka neden güvenilmediğini sorgulamıştır. Ona göre siyasal ve bilimsel meselelerde bilgi ve yetkinliğe sahip tek merci "memurîn efendilerimiz" olmamalıdır, zira mevcut durumdan da onlar sorumludur. Ahmed Midhat Efendi'nin buna cevabı, klasik devlet görüşünü yansıtmıştır. Midhat Efendi'ye göre devletin başına gelen bütün felâketlerden millet zaten haberdardır ve kendi kendine hiçbir önlem almamıştır: "En sonra dahi çare-i sslaha teşebbüs eden, sözün doğrusu askerle beraber yine heyet-i devlet” olmuştur. Osmanlı İmparatorluğu gibi “zâdegân” (aristokrat) sınıfına sahip olmayan bir siyasal yapıda bu "heyet-i devlet”, doğrudan basit vatandaşlardan istihdam edildiğine göre devlet ve millet zaten aynı şeydir (Tunaya, 2016: 78-79).

Osmanlı anayasal rejimini talep eden ve kuran yüksek bürokrasi, elindeki iktidarı anayasal şekilde paylaşmaya yanaşmamıştır. Bu dönemde ne anayasaya ne de herhangi bir ideolojiye ilişkin tutarlı bir fikir ve davranış ortaya konulabilmiştir. Zira bu bürokratların öncelikli hedefi, tıpkı kendilerinden öncekiler gibi, devleti parçalanmadan bir arada tutabilmektir. Yoksa toplum ve devlet arasındaki ilişkinin modernleştirilmesiyle pek ilgilendikleri söylenemez. Yine de şekil açısından modern kurumların yerleşmesi, siyasal otoritenin geleneğinin en saf hâline dönme imkânını ortadan kaldırmıştır. Abdülhamid’in trajedisi de budur. 


\section{SONUÇ}

Meclis-i Mebusan’n 1878'de II. Abdülhamid tarafından dağıtılmasının ardından başlayan ve 30 sene devam eden dönem çağdaşları tarafından genellikle "istibdat devri" olarak anılmıştır. İstibdat sözcüğü burada geleneksel meşru idare anlamını yitirerek modern diktatörlük rejimini ifade etmek üzere kullanılmaktadır. Bu devirde Abdülhamid, Tanzimat Devri’nden beri süregelen tüm modern siyasal kurumsallaşmayı göz ardı ederek tıpkı ataları gibi hükümdarın klasik yetkilerini kullanmayı istemiştir. Ancak Tanzimat’n mirası olan modern bürokrasi ile bu tarz bir idarenin uyuşturulması mümkün olmamıştır. Tanzimat Devri devlet adamının da demokratik saiklere sahip olmadığı ve patrimonyal habitus'una en uygun yolu seçtiği yukarıda belirtilmişti. Ancak bu devrin siyasal seçkinleri modern kurumsallaşmayı sağlamak için söz konusu patrimonyal otoriteyi modern-merkezî bürokratik aygıta yaymıștır. Böylece hem "devletlû"leri sıradan halktan ayıran status quo sürdürülmüş hem de modern siyasal sorunlara ilişkin pratik çözümler üretebilen, yetki ve sorumluluk sahibi bir idare aygıtı oluşabilmiştir. Saraydan ayrılmış ve özerk bir Bâbıâli, bu gelişmenin görünen yüzü olmuştur. Oysa 19. yüzyllın sonunda Abdülhamid Bâbıâli’nin otoritesini sonlandırıp tüm siyasal otoriteyi tekrar sarayda toplamıştır. Modern siyasal kurumsallaşmanın bu evresinde böylesi bir geri dönüş, Abdülhamid'in otoritesinin geleneksel formunu talep etmekten başka bir şey yapmamış olmasina rağmen, neo-patrimonyal modern diktatörlükle sonuçlanmıştır. Abdülhamid isminin bugün dahi bir uçta "Ulu Hakan", öbür uçta "Kızll Sultan" lâkaplarıyla beraber anılmasındaki orantısızlık tam da bu karmaşadan kaynaklanmaktadır. Zira o, patrimonyal meşruiyete tek başına sahip olduğunu varsayan geleneksel bir padişah, ama aynı zamanda da siyasal katılması bürokratik düzeyde de olsa artmış modern bir devletin tüm iktidarı tek elinde toplamak isteyen diktatörü olmuştur. 


\section{KAYNAKÇA}

ACAR, H. (2020), Tanzimat Dönemi Siyasi Liderlerinden Biri Olarak Keçecizade Mehmet Fuad Paşa. Analytical Politics, 1(1): 18-34.

AKŞİN, S. (1994), 1839'da Osmanlı Ülkesinde İdeolojik Ortam ve Osmanlı Devletinin Uluslararası Durumu. Mustafa Reşid Paşa ve Dönemi Semineri: Bildiriler (Ankara 13-14 Mart 1985), Ankara: TTK Yayınları: 5-12.

AKYILDIZ, A. (1998). Sened-i İttifak’nn İlk Tam Metni. İslâm Araştırmaları Dergisi, 2: 209-222.

AKYILDIZ, A. (2015), Osmanlı Bürokrasisi ve Modernleșme, İstanbul: İletişim.

BERKES, N. (2017), Türkiye’de Çağdaşlaşma. Ahmet Kuyaş (Yay. Haz.). İstanbul: Yapı Kredi Yayınları.

BOURDIEU, P. (1990), The Logic of Practice. Richard Nice (Trs.). Stanford: Stanford University Press.

BOURDIEU, P. (1995), Outline of a Theory of Practice. Richard Nice (Trs.). Cambridge: Cambridge University Press.

BUZPINAR, Ş. T. (2006). Mustafa Fâzll Paşa. Türkiye Diyanet Vakfı İslâm Ansiklopedisi (DİA) içinde (C. 31, ss. 300-301). İstanbul: TDV İSAM.

ÇAĞMAN, E. (2010), III. Selime Sunulan Islahat Lâyihaları, İstanbul: Kitabevi.

ÇAVDAR, T. (2004), Türkiye’nin Demokrasi Tarihi: 1839 - 1950, Ankara: İmge.

DAVISON, R. H. (1997a), Osmanlı İmparatorluğu’nda Reform: Cilt 1. Osman Akınhay (Çev.). İstanbul: Papirüs.

DAVISON, R. H. (1997b), Osmanlı İmparatorluğu’nda Reform: Cilt 2. Osman Akınhay (Çev.). İstanbul: Papirüs.

DURMAZ, S. (1997). General İgnatyev'in Midhat Paşa Hakkında Yazdığı Bir Mektup. Toplumsal Tarih, 37: 5859.

ECKSTEIN, H. (1988). A Culturalist Theory of Political Change. The American Political Science Review, 82(3): 789-804.

ENGELHARDT, E. P. (2017), Türkiye ve Tanzîmat: Devlet-i Osmaniye’nin Târih-i Islahatı 1826'dan 1882'ye. Ali Reşad (Çev.), Erol Kılınç (Yay. haz.). İstanbul: Ötüken.

GENCER, B. (2009). Son Osmanlı İmparatorluğu’nda Anayasal Akültürasyon. 100. Yillnda II. Meșrutiyet: Gelenek ve Değişim Ekseninde Türk Modernleşmesi Uluslararası Sempozyumu (22-24 Ekim 2008 Bildiriler). Prof. Dr. Zekeriya Kurşun, vd. (Ed.) İÇi̇NDE (ss.67-94). İstanbul: Marmara Üniversitesi Yayınları.

HABERMAS, J. (2015), Kamusallğıı Yapısal Dönüşümü. Tanıl Bora ve Mithat Sancar (Çev.). İstanbul: İletişim.

KARAL, E. Z. (2017), Osmanlı Tarihi V. Cilt: Nizam-ı Cedid ve Tanzimat Devirleri (1789 - 1856), Ankara: TTK Yayınları.

KEYDER, Ç. (2015), Türkiye'de Devlet ve Sinıflar, İstanbul: İletişim.

KÜÇÜK, C. (1994). Osmanlı İmparatorluğu'nda 'Millet Sistemi' ve Tanzimat. Mustafa Reşid Paşa ve Dönemi Semineri: Bildiriler (Ankara 13-14 Mart 1985). Ankara: TTK Yayınları: 13-23.

LEWIS, B. (2010), 300 Yildır Sorulan Soru: Hata Neredeydi? Harun Özgür Turgan ve Serpil Bilbaşar (Çev.). İstanbul: Oğlak. 
LEWIS, B. (2017), Modern Türkiye’nin Doğuşu. Boğaç Babür Turna (Çev.). Ankara: Arkadaş.

NAGATA, Y. (1997), Tarihte Âyânlar: Karaosmanoğulları Üzerinde Bir İnceleme, Ankara: TTK Yayınları.

ORTAYLI, İ. (2000), Tanzimat Devrinde Osmanl Mahallî İdareleri: (1840 - 1880), Ankara: TTK Yayınları.

ORTAYLI, İ. (2004), İmparatorluğun En Uzun Yüzyılı, İstanbul: İletişim.

ORTAYLI, İ. (2010), Türkiye Teşkilat ve İdare Tarihi, Ankara: Cedit.

SEYİTDANLIOĞLU, M. (1999), Tanzimat Devrinde Meclis-i Vâlâ (1838 - 1868), Ankara: TTK Yayınları.

SIYYAVUŞGİL, S. E. (1940). Tanzimat’ın Fransız Efkârı Umumiyesinde Uyandırdığı Akisler. Tanzimat I: Yüzüncü Yıldönümü Münasebetile. İstanbul: Maarif Matbaası, 747-756.

TUNAYA, T. Z. (2016), Türkiye’de Siyasal Gelişmeler (1876 - 1938), C. 1: Kanun-ı Esasî ve Meşrutiyet Dönemi (1876 - 1918). Erol Şadi Erdinç (Yay. haz.). İstanbul: İstanbul Bilgi Üniversitesi Yayınları. 